\title{
Entrance into the covenantal space as point of departure for the liturgical act of living the baptismal life in this world
}

\begin{abstract}
In an effort to rediscover the sacramental sphere in Reformed context the authors attempt to take first steps in describing anew the element of efficacy (pertaining identity-forming and transformative power) as it is envisaged in the Reformed tradition's view on the sacraments. The sense in which receiving the sacrament of Holy Baptism culminates in a baptismal life -defining the Christian identity and connecting Christians in new, transformative ways to the world they inhabit- should be considered in this quest for rediscovery of the sacramental sphere. An initial theological thesis on entering covenantal space as possible point of departure for the liturgical act of living the baptismal life in this world on daily basis is proposed. As key moment in this thesis, the integral role of a spirituality of anticipation is proposed- a spirituality that expresses itself in the sursum corda- act of entering the transcendental reality of the covenantal space where God is present, visualising and partaking (through faith) in God's vision for the newness of our lives and returning to this imminent reality bearing witness to the ultimate renewal of the whole creation. In the latter part of the paper the authors employ their theological thesis on entering the covenantal space in formulating praxis theoretical indicators for educating baptised members of the body of Christ in sacramental literacy regarding the enduring identity-forming and transformative power of their baptismal life.
\end{abstract}

\section{RESEARCH PROBLEM}

It seems difficult for Christians (at least in Reformed context) to make a connection between the historical event of their baptism (usually administered to them when they were infants) and a clear and well- developed vision on the ongoing efficacy and identity-shaping power of their "being- baptized" in daily life. The event of baptism -then- remains a vague memory from the remote ceremonial past, unable to shape the daily actions of the Christian into a baptismal life. White (1999:140) reasons that a major impediment to a richer sacramental life still seems to be the reluctance to see sacraments as present acts of God rather than mere human memories of God's acts in the past. It is difficult for many Protestants to conceive of sacraments as God's self-giving. Therefore little sense of sacramental efficacy survives among many Protestants. For Wainwright (1978:37) the moves introduced by Protestant reform (that amount to pruning the ceremonial and multiplication of explanatory words and doctrinal instruction) paid a price in the loss of the sacramental dimension and in the growth of didacticism. In his work The Protestant Era (1948) Paul Tillich reminds us that a rediscovery of the sacramental sphere is needed for Protestantism to come to its full realization. This would involve the realization that natural objects can become bearers of transcendent power and meaning by being brought into the context of the history of salvation.

The need for "a rediscovery of the sacramental sphere" is emphasised from various angles in recent Protestant thinking. For White (1999:141) careless and unthinking practice and a lack 
of teaching the meaning of sacraments has left a generation sacramentally illiterate. Dircksen (2010:373) -working with perspectives from the human science, anthropology- bemoans the praxis in which the sacrament of baptism is too easily associated only with the category of ceremony. The identity-forming and transformative power of ritual (like it is acted out in rites of passage) is -according to Dircksen- under-utilized in the sacramental sphere. She proposes that a religious leader should become a ritual leader in the initiation process of young congregants in order to prevent them from falling into chronic liminality. Van der Merwe (2009:130) considers the phenomenon that a substantial number of Christians in Reformed contexts feel the need to undergo the so- called baptism of faith as a second form of baptism- and in the process undercutting any sense of the activity of God in the previous baptism. This phenomenon challenges religious leaders to reconsider the element of active participation in and ongoing significance of the sacrament of baptism. This element of active participation - according to Van der Merwe- challenge leaders to educate members in how we can grow in our identity as baptised people and to identify what elements regarding frame of mind, attitude and disciplines of faith are representative of the baptismal life.

As far as we- the authors of this article are concerned- the quest for rediscovery of the sacramental sphere in Reformed context can be aided to a large extent by asking what ought to happen in order for the following vision of Batchelder (2006:11) to be realized: "Baptism is a life we must grow into, walking a path of ongoing formation. This path involves a process of living into and living out a new identity as a graced member of Christ's corporate body. Being baptized connects us in new ways to the world we inhabit and transforms these relationships so they possess a new character and ethical imperative."

In this paper we explore the practical theological implications of the action-fields and the senses of liturgical space contained in above mentioned vision by:

- Attempting to take first steps in rediscovering the element of efficacy (especially pertaining identity-forming and transforming power) envisaged in the Reformed tradition's criteria for defining sacraments (specifically the sacrament of Holy Baptism);

- Proposing an initial theological thesis on entering covenantal space as possible point of departure for living the baptismal life in this world on daily basis;

- Formulating initial praxis theoretical indicators for educating baptised members of the body of Christ in sacramental literacy regarding the enduring identity-forming and transformative power of their baptismal life as it is anchored in and energized by constant entry into the covenantal space.

\section{REDISCOVERING THE ELEMENT OF EFFICACY IN THE REFORMED TRADITION`S VISION ON THE SACRAMENTS (SPECIFICALLY PERTAINING THE SACRAMENT OF HOLY BAPTISM)}

By sacramentality -according to White (1999:13)- is meant the concept that the outward and visible can convey the inward and spiritual. Physical matters and actions then can become transparent vehicles of divine activity and presence. It is important to note that in this definition of sacramentality -as we interpret it- the focus is not exclusively on the aspect of matter or stagnant, isolated association (for example the symbolic meaning of water in itself reduced to a bare sign mechanically administered) but also encompasses the idea of ongoing, life-changing action (lasting identity-forming and action-inducing effects implicated by being baptised and the durative relationship dynamic between divine actions and human actions). By emphasizing the element of ongoing action a key notion in the Reformed view on the efficacy of sacraments is 
affirmed in that it is made clear that the physical elements have no automatic force in themselves, but that Christ and the Spirit work through them to apply salvation (Lusk, 2004:71)

Calvin's defined a sacrament as "an outward sign by which the Lord seals on our consciences the promises of his good will toward us in order to sustain the weakness of our faith; and we in turn attest our piety toward him in the presence of the Lord and of his angels and before men" (Institutes of the Christian Religion, IV.14.1). Underlying this view on the sacraments is a covenantal theology that stresses a relationship of trust and lasting commitment between the graceful God and his people. From this perspective sacraments are viewed not only as signs and symbols but as seals of the covenant. In other words the sacraments do not merely serve as signs to remind the believer that there is a covenant. Nor do they merely symbolically portray something about the covenant. Instead as a "seal" the sacrament does something when one receives it (Lane, 2008:177). It fills the believer with confidence and living hope regarding the fulfilment of God promises. Calvin repeatedly insisted that the grace objectively offered in the sacrament must be subjectively received by faith. This dialectic of offer and reception is according to Evans (2005:78) foundational for a proper understanding of Calvin's doctrine of the sacraments in general and is perhaps the most important element distinguishing Calvin's approach to baptismal efficacy from that of Rome. In drawing the lines of this distinction it should be noted that a particular current of Catholic sacramental theology is implicated, namely the onto-theological model. This model insists on the objective efficacy of the sacraments and should be distinguished from other lines of thinking in Catholic sacramental theology like the Vatican II model. Vatican II attempts to harmonize the traditional current, which considers the sacraments "means," and the newer, which insists on their function as expressive signs (Chauvet, 1995: 411, 415).

Calvin proceeds to explain that the sacraments properly fulfil their office when the Spirit, that inward teacher, comes to them, by whose power alone hearts are penetrated and affections moved and our souls opened for the sacraments to enter in. If the Spirit is lacking, the sacraments can accomplish nothing more in our minds than the splendour of the sun shining on blind eyes, or a voice sounding in deaf ears. The traditional Reformed confessions and catechisms make it clear that the sacramental elements do not operate on their own. The efficacious operation at work in the sacraments depends upon the Holy Spirit, who operates through the sacraments as He does through the Word. This according to Bromiley (1999:405) is a crucial point in Reformation teaching (cf. Geneva Catechism (1545) 2.84; Gallican Confession XXXIV; Belgic Confession XXXIII; Second Helvetic Confession XIX).

In shifting the focus of the discussion to the element of efficacy in the sacrament of Holy Baptism, an overview of the New Testament perspectives on baptism should be considered culminating in a brief analysis of how efficacious working imbedded in these perspectives are interpreted and confessed in the traditional Reformed confessions, baptismal formularies and catechisms.

According to White (1999:53) the chief New Testament metaphors for baptism are five (frequently overlapping and always complimenting each other):

- Forgiveness of $\sin$ (Acts 2:38; 1 Corinthians 6:11)

- Union to Christ (especially in his death and resurrection) (Romans 6:3; Colossians 2:12)

- Incorporation into the church (1 Corinthians 12:13; Galatians 3:27-28)

- Reception of the Holy Spirit (Acts 2:38)

- New birth or regeneration (John 3:5; Titus 3:5)

Atkins (2004:48) summarizes the implications of these metaphors for baptism as follows: God is 
the one who at our baptism takes the initiative and declares that we are:

- Children of God,

- Called by name,

- Members of the whole Christian community.

And therefore,

- Sealed as prophets, priests and kings,

- United in Christ,

- Gifted with the Spirit,

- Raised to new life.

It is clear from the action fields imbedded in these New Testament perspectives that baptism is essentially something which God does and to which we respond, rather than our action to which God is gracious enough to respond. We are who we are because God has loved us, chosen us, adopted us, anointed us to be his own. Through baptism, a Christian first and finally learns who he or she is. It is the rite of identity (Willimon, 1980:27, 28). The efficacious working of the baptism (when viewed for the action fields present in the covenant environment) consists of God working in us, the members of the Christian community, through his Spirit a sense of our new identity in Christ and the will to live the new life He has given us.

The efficacious element imbedded in these perspectives are interpreted and confessed in the traditional Reformed confessions, baptismal formularies and catechisms along the following lines:

- By baptism we are received into the church of God (Gallican Confession XXXIV). Being marked as a Christian comprises embracing the new Christian identity and acting out the Christian ministry of prophet, priest and king we are consecrated unto. Baptism is a sign of our profession (Anglican Thirty-Nine Articles XXVII). Baptism -once receiveddoes continue all one's life, and is a perpetual sealing of our adoption (Second Helvetic Confession, $\mathrm{XX}$ ).

- Baptism, like circumcision, is a covenant sign. It is a "sign and seal of the covenant of grace" (Westminster Confession XXVIII, 1). It operates in the action field of God's effective grace through the forgiving and cleansing working of the blood of Christ ministered by the Holy Spirit and God's faithful promise to fulfil what He has started in us (Heidelberg Catechism Qu. 74). The covenant idea found in the classical baptismal formulary of the Reformed tradition as developed by Olevianus and Ursinus and formulated in the church order of Paltz (1563), does not reflect an abstract idea. What is evident in this formular is the notion that God's acts in Christ are very real. These acts from God are radical and total and call for a radical and total commitment (van`t Spijker, 1980:11).

- What should also be noted in the text of the above mentioned formular is that activity of triune God is not spoken of in past tense. The Father seals to us by baptism that He establishes an eternal covenant, and wants to provide for us and protect us against evil or let evil work to our own good; The Son seals to us that He washed us with his blood (inaugurating us into his death and resurrection) with the result that we are saved from sin and reckoned justified before God; The Spirit seals that He wants to live in us and sanctify us to become members of Christ and wants to let us partake in the riches that we have in Christ, consisting of the cleansing of sin and daily renewal of life, until we will be 
established in eternal life without blemish. The continuous, all- encompassing activity of God is answered by covenant activity by us that speaks of constant and daily commitment (loving God with whole heart and soul), striving against enemies, and living a life of godliness. And when we fall in sin due to our weakness, we can focus on baptism as a seal (undoubting witness) that we have an eternal covenant with God (van `t Spijker, 1980:24). These actions imply that sacramentality does not have to do with liturgical events that only from time to time trigger memory, but supposes a constant consciousness of being in a personal relationship with God.

- Baptism is a bath of regeneration that the Lord offers to his elect pointing very powerfully to the believers' dying with Christ and rising again with him. (First Helvetic Confession, XXI; Heidelberg Catechism Qu. 72). By it the elect of God are consecrated unto God (Second Helvetic Confession II, XX). Regeneration means both putting on us the new man, and putting off the old man with his deeds (Geneva Catechism (1545) 2.86; 2.87; Belgic Confession XXXIV). Here the ethical thrust of baptism is clearly seen. Baptism is not a single event. It works itself out in total renewal (Second Helvetic Confession II, XX).

- Baptism simultaneously sets a person apart and incorporates him or her in a community, the new community of the Church, united in Christ (Heidelberg Catechism Qu 74). The sacraments are thus about salvation, not as a gift turned in on itself, but as something that reaches much further than the well- being of the individual believer. The communal baptismal life aim toward the liberation of mankind united under one Head, Christ (cf. Lukken, 2005:386; Spierling, 2005:4).

- Baptism is not efficacious simply by being administered. It is asked whether "the water is a washing of the soul". The answer is "by no means" (Geneva Catechism (1545) 2.86). Only the blood of Christ can wash the soul. In order that it may do this by way of baptism, a first prerequisite is faith. Baptism is the sacrament of faith (Gallican Confession XXXV; Geneva Catechism (1545) 2.87; Anglican Thirty-Nine Articles XXV). The right use of baptism consists in faith and repentance (Geneva Catechism (1545) 2.87). (Bromiley, 1999:406- 411)

Rediscovering the element of efficacy in the Reformed tradition's vision on the sacraments (specifically pertaining the sacrament of Holy Baptism) -in our view- amounts to relocating the working of the sacrament to the action fields at work in the covenant of grace. Liturgical acts aimed at activating the efficaciousness of the sacraments -then- do not only comprise of special (and isolated) events like special baptism services (allowing every Christian present to call to mind their own baptism and what God did then and does now for God's children or encouraging the congregation to return to the symbolic place of their baptism to sprinkle themselves again with water (cf. Atkins, 2004:50). Liturgical acts -and this is to our mind the heart of rediscovering the element of efficacy in the Reformed vision on the sacrament- should in the context of the covenant of grace bring members of the Christian community in continuous strengthening, regenerating and focusing contact with the Author of their identity and the newness of their life in a world that is destined to be renewed by the One that says: "See! I make all things new." (Revelation 21:5)

In the next section of our paper we propose an initial theological thesis on entering covenantal space as a possible point of departure for the liturgical act of living the baptismal life in this world.

\section{AN INITIAL THEOLOGICAL THESIS ON ENTERING COVENANTAL SPACE AS POSSIBLE POINT OF DEPARTURE FOR THE LITURGICAL ACT OF LIVING THE BAPTISMAL LIFE IN THIS WORLD}


Taking the cue from the spatial theories of scholars like Henri Lefebvre and Edward Soja, Cilliers (2008:2) distinguishes between at least three possibilities in describing the concept of space: "Firstspace" - which can be chartered and indicated geographically; "Secondspace", which indicates imagined space (concepts, ideas on how space is or should be); "Thirdspace", i.e. lived or existential space, which indicates the immediate, real surroundings in which people find themselves every day (cf. Berquist, 2008:41). In order to facilitate the liturgical understanding and function of space, Cilliers (2008:3) ventures to identify a further distinction: "Fourthspace", which links to "Secondspace" (imagined space), but also transcends it. "Fourthspace" could be called anticipated space, in the sense of an anticipatory prolepsis of transcendent realities, in such a manner that not only imagined space is viewed from a distance, but rather that the viewer already partakes in the object of prolepsis. The transcendent reality enters the viewer's immanent reality, but never to the degree where the transcendent reality can be grabbed and controlled; rather the viewer takes hold of it through faith. To understand (and enter) this form of space one needs a distinctive form of spirituality, and therefore "Fourthspace" could also be called a spiritual space, calling for a spirituality of anticipation.

What Cilliers calls a spirituality of anticipation is representative of a key moment in our thesis pertaining to the liturgical act of living the baptismal life in this world. In our view a spirituality of anticipation essentially has to do with the sursum corda-act of entering the transcendental reality of the covenantal space where God is present, visualising and partaking (through faith) in God's vision for the newness of our lives and the ultimate renewal of the whole creation. But the act also entails returning to the immanent reality of this world radiating the living contact with God (cf. 2 Corinthians 3:18) and anticipating/ bearing witness of something better foreseen for this world than the brokenness and polluting and disintegrating powers still at work in the world in its current state (cf. Romans 8:21).

In exploring Biblical conceptualization regarding covenantal space and to illustrate what the liturgical act of entering the covenantal space entails, a brief reference can be made to two images: entering the Promised Land and entering the sanctuary.

\section{Entering the covenantal space of the Promised Land}

Part of the covenant promise described in the Old Testament deals with the very concrete promise of land: Israel being led out of land of slavery into land where life can flourish under God's reign. The view that the new covenant, in contrast to the covenant with Abraham, is essentially spiritual and therefore not concerned with something as material as the word "land" suggests, can- in our view- seriously impede the contemporary believer in seeing the relevance of his/ her Christian faith for living the baptismal life in this world. Inherent to this belief can be the idea that for something to be spiritual, it must be non-material. But for many this means it is less than real, because reality consists of what can be touched-substantial matter that occupies space (Armerding, 2000:220). We concur with Armerding (2000:223) that Protestants have little theology of land and sometimes little theology of creation in general. Entering covenantal space (fourth space) entails the anticipatory act of entering a heavenly country (According to the writer of Hebrews, Abraham and the patriarchs longed for a better country- a heavenly one' (11:16)). But entrance into the heavenly country does not implicate spiritualizing estrangement from this world. The proleptic act of tasting the first fruits of God promised new life and seeing proof of God's grace in our regenerated nature, causes us to return to and live in this world with the living hope of the promised renewal of the whole creation and with renewed focus to bear prophetic witness to this imminent liberation of creation.

\section{Entering the covenantal space of the sanctuary}

The sanctuary is a central Biblical concept for signifying living contact with God in a reconciled and 
sanctified space. Factors that caused tension and estrangement in the relationship (ungodliness of man and covenant unfaithfulness) are reconciled so that atonement can take place and man can draw near to God. Only because the tabernacle of the wilderness was constructed precisely "according to the pattern" shown to Moses on the mount could a worship pattern provide insight into the realities of a proper approach to God under the provisions of the new covenant (Hebrews 8:5). Instead of moving toward a worship centre localized in modern-day Jerusalem, the newcovenant believer joins with the angels to worship at the "heavenly Jerusalem, the city of the living God" (12:22; cf. Robertson, 2000:122). They draw near and enter the heavenly sanctuary on the new and living way opened up by Jesus Christ with a sincere heart and in full assurance of faith (Hebrews 10:19-25). Yet again the daily sacramental act of entering this sanctified space filled with the confidence flowing from God's covenantal faithfulness that through the cleansing and regenerating acts of Jesus nothing can separate us from $\mathrm{Him}$, does not estrange/isolate us from this world we live in. It fills us with joy and anticipation to see that the reconciled life with God and the integrity and joy it brings to us, will extend to whole of creation when every space will be filled with his presence and glory. So that He may be all in all (cf. 1 Corinthians 15:28).

It is very challenging to develop a theory for educating the Christian community partaking in the blessing of the sacrament of Holy Baptism that culminates in constantly realizing and living out the sacramental implications of their baptism. It is especially challenging when the thesis worked with, does not only take concrete, easily associable elements (like for instance the symbolic meaning of water and concrete rituals performed during worship services) into account. Our thesis especially focuses on anticipatory acts of faith. These acts- when not explained carefully and thoughtfully- can very easily be relegated to the category of abstract and it can therefore become very difficult to associate these acts with the reality of life in this material world. In the next section we attempt to take up this challenge in formulating initial praxis theoretical indicators for educating baptised members of the body of Christ in sacramental literacy regarding the enduring identity-forming and transformative power of their baptismal life as it is anchored in and energized by constant entry into the covenantal space.

\section{FORMULATING INITIAL PRAXIS THEOLOGICAL INDICATORS FOR EDUCATING BAPTISED MEMBERS OF THE BODY OF CHRIST IN SACRAMENTAL LITERACY REGARDING THEIR BAPTISMAL LIFE}

Nobody can answer to God's promises sealed in baptism without the regenerating work of the Holy Spirit. Infant baptism presupposes the working of the Spirit through the education of parents and teachers in the life of the baptised person. Jesus in His command to His disciples connected baptism and teaching inseparably (Matthew 28:19-20).

The question we attempt to answer in this section deals with how the church -through its teaching and actions- can be the best instrument in the hands of the Holy Spirit to lead the baptised to live in a covenantal relationship with God and his people so that they can experience the identity-forming and transformative power that is signified, sealed and promised in their baptism.

In order to guide a person in the art of living abundantly out of the promises of his/her baptism within the intimate space of the covenant, the essence of that space should be known. By answering the question about the essence of the covenantal space we will also be able to answer the question mentioned in the previous paragraph. When you know what the covenantal space is (that is: what you receive in this space and what you ought to do and be because you are in this particular space), you will be able to address the question regarding educating the people of God to live in this space. 


\subsection{Entering into the covenantal space is entering into a space that you are already imbedded in}

God created the covenantal space. God made the covenant with Abraham and through Christ with every believer and their children (Galatians 3; Chapel, 2003:11). Christ made the creation of this space possible with His atoning work. The Holy Spirit creates a new space, a new life, inside man which will make it possible for that person to live with joy in the covenantal space.

Infants of believing parents -as we see it- were already part of the covenant from the moment of conception. All the promises of the covenant are theirs (Wilson, 2003:293). They are in a covenant relationship with God. The child has no choice in it. There is no escape from this disposition for the rest of his life. Baptism seals this relationship with the sign of water. This can be compared to a child born to certain parents. The child can feel at home in the space shared with the parents. He is not treated as if he does not belong there. Covenantal space is not an unfamiliar country that must still be conquered. It is also not a space that can be put behind you as if you never partook in it. Once God has made his covenant with you, it is a lifelong covenant from His side. All a child of the covenant can do is to accept or reject God's attentions and promises. But the promises of God cannot be made undone (Brueggemann, 2001:83).

Brueggemann (1999:1-17) speaks of God as the "other" in man's life. "This "other", he says, "is a endlessly inscrutable mystery and endlessly problematic to us, for we can neither escape from that other, nor are we able to seduce, capture, or possess that other who always stands from and over against us." (1999:1) Baptism is a token and seal that this "other" has chosen you to be part of his covenant. It is a token of the lengths he went to, to make it possible for you to live in the closest, covenantal, relationship with Him and his people. With this comes his demand that you should give your whole life to Him. In this a baptised child has no choice. He/she is in this covenantal space. The psalmist was stricken by this fact when he wrote these words:

LORD, you have examined me and you know me. Where can I go from your Spirit, or where can I flee from your presence. I ascend to heaven, you are there; If I make my bed in sheol, you are there. (Ps 139:1,7,8)

For the baptised to experience the identity-forming and transformative power, that is possible in this space, he must know this God to whom he is connected by the covenant. Heitink (2008:299) says: "Godskennis is een wijze van kennen die opkomt uit een zich gekend weten" (Freely translated in English: The knowledge of God flows from the knowledge that you are known.) This way of knowing asks from you to open yourself to the transcendental reality that exists imperceptible behind our reality, so that it can sometimes, for a moment, be experienced as a perception of being known.

Dean (2010) discusses the results of National Study of Youth and Religion in America. The results show that the churches under scrutiny in the survey taught their youth a feel good therapeutic gospel that doesn't ask anything of the individual. These young people say they don't have a problem with the gospel and God, but it is also clear out of the survey that they don't feel much for God and they don't know much about Him. People can be indifferent to God only because the church let them be.

The church must teach a God that cannot be escaped; A God that comes to you in your baptism with His love and His promises. You have to either reject Him or love Him but you can't ignore Him. Van der Merwe (2009:136) calls baptism a drowning of the child, because baptism calls for dying in yourself to be resurrected by the Spirit in Jesus Christ (Galatians 2:20).

The church must teach Jesus Christ as the One on whom you either build your life or find him to be a stumbling block and a stone that crushes you. The church must teach and live in such a 
way, that nobody can stay indifferent. The uncompromised message to the baptised must be: "you are in the covenant space by the grace of God, live in that space with your whole heart, mind and strength". It must be impossible for an onlooker to be in the presence of God's people, and in the process not meeting God or seeing the fear of the Lord in their lives. Everything the church does must be a proclamation of God as He makes Himself known in Scripture and the covenant (Robbins, 1990:121).

Maybe that was what Paul had in mind when he wrote to Timothy:

In the presence of God and of Christ Jesus, who will judge the living and the dead, and because he is coming to rule as King, I solemnly urge you to preach the message, to insist upon proclaiming it (whether the time is right or not), to convince, reproach, and encourage, as you teach with all patience (2Timothy 4:1,2).

The second aspect of covenant space that is important for the church to help the baptised in unlocking and sustaining the identity-forming and transformative power of their baptism is to know and experience that:

\subsection{Covenantal space is a familial space}

When God made the covenant with Abraham, he said that he will be a God to him and his children. From the start this covenant has been closely associated with the household of parents including their siblings and descendants. God even commanded Abraham to circumcise his whole household (Genesis 17:12). Chapel (2003:13) calls this incorporation into the covenantal status of the parent, the representative principle: "The representative principle also explains why, in the New Testament, the apostle Paul could still say that children of a believing parent, - even one who is married to a non-believer- are "holy" before God (1 Corinthians 7:14)." God gives His covenant promises to every believer and when that believer has children those particular children are partakers of the covenant. God pledges all the blessings of the covenant to the believer and his children when the condition of faith is met. Furthermore everyone that partakes in the covenant is also part of God's holy nation.

This implies that the education of the Christian community is a family business. In order to partake in the blessing of the sacrament of Holy Baptism in a way that culminates in constantly realizing and living out the sacramental implications of your baptism, you have to be part of God's people (Heitink, 2008:158).

What the covenant blessings amount to and how the member of the Christian community can experience these blessings as a reality in his/her life, are best taught and learned in the loving relationship of a family and in the community of saints.

As an example, it can be stated the relationship of a new born baby with his mother, proves to be all important for the development of his relationship to God. If the baby experience unconditional love from his mother, knowing that she is there for him when he needs her, it will be easier for him to believe in an almighty God who is his Shepherd (Montanaro, 1994:17-25). If he also learns to respect and obey his parents -even if he doesn't understand the logic behind their decisions-, it will prepare him to serve the God of the covenant who asked from Abraham to sacrifice his son. If he learns to respect his parents but at the same time has the freedom to talk to them about his pain and his need he will be able to, while he fears the Lord, draw near to Him with boldness (Hebrews 10:19-25). If he learns that his parents won't except bad behaviour but that they will forgive him, he will more likely be able to understand God's forgiveness in Jesus Christ and God's demand to be holy as He is holy (Brueggeman,1999:3-6). If he learns to serve other, seeing his parents serve others, it is a preparation for him to be able to give himself as an 
offering to God (Romans 12:1). Strommen \& Hardel (2000:85) say that values are communicated most powerfully by parents. The power of a peer group's influence "emerges as dominant only when the relationship of love with parents is vastly diminished".

What we are saying is that the Holy Spirit can use healthy covenant family relationships to prepare a child for his relationship with God.

A church that wants to live out of the covenantal relationship -as it is sealed in baptismhas to incorporate a ministry that promotes healthy families. Families must actively be guided in areas like the following: Parental harmony, effective communication, wise parental control, parental nurturing (Strommen \& Hardel, 2000:37-71).

The same is true for the relationships in the congregation. The congregation must be a family. Strommen \& Hardel (2000:158) list eight factors that make congregations a family: A hospitable climate, inspirational worship, a caring environment, a thinking climate, families who help families, an emphasis on prayer, intergenerational service efforts and a sense of mission. A congregation who sets its target to be a family in this way will make constant entrance into the covenantal space a natural part of their baptismal life. If this is done in obedience to God, both those who are on the receiving side and those who are ministering to them will be connected to God's purpose with His covenant. This will bring hope to both sides and the anticipation of the work of the Holy Spirit in all of them.

The church must know what it is, namely the covenant family of God, the church must do what it is, and the church must organise what it does. In this way, entering the covenantal space must be communicated as being part of the baptismal life of the church and not as if it amounts to a sporadic event. Pickard (2009:6) formulates this fact as follows: "The people of God do not decide of their own accord to operate in a collaborative manner. The ecclesia is, by virtue of being the body of Christ, a collaborative entity. ... As a result when the Church acts in a collaborative manner it actualises its own deepest reality"

\subsection{Covenantal space is a charismatic and diaconal space}

When God made the covenant with Abraham He communicated the essence of the gospel to him when he said "Through you all nations will be blessed" (Galatians 3:8). This blessing to the nations culminated in Jesus Christ and his sending of the Holy Spirit. When Jesus ascended to heaven as king he gave gifts to his Church so that they could be a blessing to the nations (Ephesians 4:7, 8). Each believer received a gift by God's grace and as good servant- managers of God's grace they must serve others with their gifts (1 Peter 4:10). Jesus gave certain focused gifts to equip members of the congregation for their service in his kingdom (Ephesians 4:11-13).

Equipping every member for a special task must be a priority in the congregation. The structure of the congregation's ministry has to make it possible for every member to use his or her gift. In this way the congregation will spread the love and grace of God according to their baptismal calling.

This also defines the congregation as a missional body. Jesus who came to fulfil the covenant, also came to seek and to find those who are lost. The task of the congregation is to find the proverbial sheep that belong to the herd that Jesus purchased for his Father (John 10).

A Spirit-filled congregation, orientated towards service, can expect to experience the mighty deeds of God in the covenantal space of which their baptism give testimony.

\subsection{Covenantal space is a space of growth}

The members of the body of Christ can only grow to full maturity by being equipped for their ministry and by ministering to each other and the people outside the congregation (Ephesians 4:7-16). The covenant people of God have received all that are necessary for them to live and to 
serve God, therefore they must do everything to grow in their faith so that they can live joyously in the kingdom of Christ (2 Peter 1:3-11). Because the covenant people were regenerated by the Word of God, they must grow in their love for each other (1Peter 1:22-23). In Hebrews 6:1-12 the congregation is warned that somebody who in many ways receives the grace of God but doesn't respond by producing fruit, becomes worthless and will be judged by God.

Jesus said that those who hear the Word of God and don't respond to it, will lose the little that they have. But they that receive the Word, keep it in their hearts and serve God with their lives, will accumulate more and more knowledge (Luke 8:18). You can only experience God's covenantal gifts when you grow constantly in your knowledge, your love and your ministry to God and men.

Brueggemann (2001:83) says that in Deuteronomy 6:4 ("Hear Israel YHWH is one"), the addressed group is "always being formed, re-identified, and reconstituted as the Israel of God, for Israel becomes Israel through hearing". The imperative "hear" is fundamental to a covenantal understanding of this people of God. In his second letter Peter says the same thing: "And so I will always remind you of these matters, even though you already know them and are firmly grounded in the truth you have received" (2 Peter 1:12). The congregation can only live in covenantal space by hearing the truths of God over and over again. If the Word of God is constantly applied to the lives of the congregation members in sermons and by means of teaching the sound doctrine, they will be firmly grounded in the truth. If they continuously meet the God of the covenant, they won't forget their identity.

A congregation should have various opportunities to grow in their knowledge of God as He is revealed in his Word. By the teaching ministry they must consciously be led into the covenantal understanding of the space they find themselves in at that moment of their lives.

\subsection{Covenantal space is representative of unfinished business}

In this life there will always be something incomplete concerning our relationship with God and each other. Entering and re-entering the covenant space, understanding and trying to fully understand, enjoying and grieving the consequences of being in the covenant space, will always be part of our life with God on this earth. Paul says he finds in himself the desire to do good, but he is still sinning (Romans 7:21-23), and despite all his knowledge of Christ he is still stretching out to take hold of this knowledge (Philippians 3:10-12).

Covenant people are always looking forward to the second advent of Jesus Christ. This process of entering and re-entering the covenant space - the space that the believer always sensed that he/she belongs to- will be consummated on that day. On that day we will fully experience the grace of God that He intended for us in his covenant.

A South African poet renowned for his role in the first Afrikaans Bible translation, JD Du Toit (Totius), once said "Die wêreld is ons woning nie", (Free English translation: "The world is our home not"). Our baptism seals the fact that we have another home with our Father in heaven. Entering the covenantal space in this life and enjoying the presence of our Lord, will always awaken the anticipation for another day when we will enjoy this privilege in a much deeper sense and will also make us expect the day of eternal perfection.

\subsection{Covenantal space is a space of celebration}

Out of the preceding discussion it is clear that entering covenantal space is a matter of remembrance, a matter of living out that remembrance and a matter of making the consequences of that remembrance a reality in your life. Remembrance and living out of remembrance, create experiences that confirms the truth of the covenantal promises and that in their part creates anticipation of more to come. 
Covenantal space is a space that should be remembered by celebration. God gave Israel various feasts to celebrate the covenant relationship. Pious Jews tried to get to Jerusalem at least for the annual festivals of Passover, Pentecost and Tabernacles, in accordance with the Law (Exodus 23:17; Beckwith, 1978:42). In the new covenant the two sacraments of the Holy Communion and Holy Baptism were instituted by Christ. But there are more opportunities to celebrate Gods faithful covenantal acts and -in the process- being reminded of the rejuvenatory newness of life that flows from God's redemptive acts. A congregation can celebrate significant redemptive historical events like the birth, death and resurrection of Christ, ascension and Pentecost and use the liturgical acts involved in commemorating these events as opportunity to bring the covenantal relationship between them and God into remembrance. A family can celebrate each member's date of baptism year after year calling into memory all that their baptism entails. Also when a member comes to the point of confession of his/ her Christian faith in the midst of the congregation, it can be a cause for the celebration of the newness of life that flourishes in the covenantal space.

\section{SUMMARIZING REMARKS}

In taking first steps with the eye on rediscovering the elements of efficacy envisaged in the Reformed tradition's criteria for defining the sacramental sphere of Holy Baptism, we focused in this paper on the idea of lasting, identity-forming and action-inducing effects implicated by being baptised and the durative relationship dynamic between divine actions and human actions in this particular liturgical action field.

In attempting to give shape to above mentioned focus, we proposed an initial theological thesis on entering covenantal space as possible point of departure for living the baptismal life in this world on daily basis. In our thesis the sacramental sphere (particularly the element of efficacy at work in this sphere) is located in the context of the covenant of grace, bringing members of the Christian community in continuous strengthening, regenerating and focusing contact with the Author of their identity and the newness of their life in a world that is destined to be renewed. As key moment in our thesis pertaining to the liturgical act of living the baptismal life in this world, we proposed the integral role of a spirituality of anticipation, that expresses itself in the sursum corda- act of entering the transcendental reality of the covenantal space where God is present, visualising and partaking (through faith) in God's vision for the newness of our lives and returning to this imminent reality bearing witness to the ultimate renewal of the whole creation.

In attempting to develop initial practice theoretical indicators for educating the Christian community regarding the liturgical act of constantly realizing and living out the sacramental implications of their baptism by entering the covenantal space, we identified the following indicators:

- Accompanying the Christian community in the liturgical act of entering the covenantal space, entails defining and embracing this space as a space that you belong to and are already partaking in through the grace of God. It is not an alien space that awakens a perception of not belonging to.

- What the covenant blessings entail and how the member of the Christian community can make these blessings a reality in his/her life, is best taught and learned in the loving relationship of a family and in the community of saints.

- A congregation's ministry should be structured in a way that enables every member to use his or her gift in bearing witness to the newness of life received through the grace of 
God in his presence. In this way the congregation will spread the love and grace of God according to their baptismal calling.

- The reality of God's covenantal gifts can only be experienced when a member of the Christian community is equipped to grow constantly in his/her knowledge, love and ministry to God and men. Baptismal identity and transformation into newness of life should constantly be invigorated by enduring spiritual discipline that stimulates growth according to the fullness of Christ

- Covenant people should constantly be reminded to anticipate the second advent of Jesus Christ. The process of entering and re-entering the covenant space - the space that the believer always sensed that he/she belongs to- will energize the baptised person's calling by anticipating its consummation on the day of Jesus' return.

- Members of the Christian community should be enabled to remember the rejuvenatory nature of the covenantal relationship by celebrating key redemptive events in the establishment and renewal of this relationship commemorated in key events of the Christian calendar like Advent, Easter and Pentecost.

\section{BIBLIOGRAPHY}

Amerding, C.E. 2000. Stewardship of the land: a Christian mandate (In P. Johnston \& P. Walker, eds. The land of promise- Biblical, theological and contemporary perspectives. Downers Grove: InterVarsity, p. 215-231).

Atkins, P. 2004. Memory and liturgy- The place of memory in the composition and practice of liturgy. Aldershot: Ashgate.

Batchelder, D.B. 2006. Living wet: baptismal remembrance and life at the edge of dawn. Liturgy, 21 (4): 11-17.

Beckwith, R.T. 1978. The Jewish background to Christian worship. (In C. Jones, G. Wainwright \& E. Yarnold, eds., The study of Liturgy. London: SPCK, p.39-51).

Berquist, J.L. 2008. Spaces of Jerusalem. (In J. L. Berquist and C. V. Camp, eds., Constructions of space II The biblical city and other imagined spaces. New York: T\&T Clark, p.4-52).

Bromiley, G.W. 1999. Baptism in the Reformed Confessions and Catechisms. (In S. E. Porter and A. R. Cross, eds. Baptism, the New Testament and the Church - Historical and contemporary studies in honour of R.E.O. White (Journal for the Study of the New Testament supplement series 171). Sheffield Academic Press: Sheffield, p. 402-418).

Brueggemann, W. 2001. Deuteronomy. Abingdon Old Testament Commentaries. Nashville: Abingdon press.

Calvin, J. 1960. Institutes of the Christian Religion, ed. J. T. McNeill, trans. F. L. Battles. Philadelphia: Westminster Press.

Chapel, B. 2003. A Pastoral overview of infant Baptism. (In G. Strawbridge, ed. The case for covenantal infant baptism. Phillipsburg: P\&R Publishing, p.9-29).

Chauvet, L-M. 1995. Symbol and sacrament: a sacramental reinterpretation of Christian existence. Collegeville: The Liturgical Press.

Cilliers, J. 2008. In die omtrek van die Gees: 'n besinning oor die ruimtelikheid van liturgie. Praktiese Teologie in Suid-Afrika, 23(2): 1-22. [In the radius of the Spirit: Considering the spatiality of liturgy. Practical Theology in South-Africa, 23(2): 1-22.]

Dean, K.C. 2010. Almost Christian: what the faith of our teenagers is telling the American church. Oxford: Oxford University Press.

Dircksen, M.R. 2010. Die doop, geloofsbelydenis en nagmaal: ware inisiasie of seremonie? Ekklesiastikos Pharos, 92: 368-376. [Baptism, confession of faith and Eucharist: true initiation or ceremony? Ekklesiastikos Pharos, 92: 368-376).]

Evans, W.B. 2005. "Really exhibited and conferred. In his appointed time": Baptism and the new Reformed sacramentalism. Presbyterion 31(2): 72-88.

Heitink, G. 2008. Een kerk met karakter. Tijd voor heroriëntatie. Kampen: Kok.

Lane, D.C. 2008. Some difficulties in covenant theology's view of baptism as a "seal". Blbllotheca Sacra, 
165: 164-77.

Lukken, G. 2005. Rituals in abundance - Critical reflections on the place, form and identity of Christian ritual in our culture. Leuven: Uitgeverij Peeters.

Lusk, R. 2004. Paedobaptism and Baptismal Efficacy: Historic Trends and Current Controversies, (In S. Wilkins and D. Garner, eds., The Federal Vision. Monroe: Athanasius Press, p. 71-125).

Montanaro, S.Q. 1994. Helping the Child. (In S. Calvaletti, P. Coulter, G. Gobbi \& S.Q. Montanaro, eds., The Good Shepherd and the Child: A Joyful Journey. Chicago: Liturgy Training Publications, p. 17-26).

Pickard, S. 2009. Theological foundations for collaborative ministry. Burlington: Ashgate.

Robertson, O.P. 2000. A new-covenant perspective on the land. (In P. Johnston \& P. Walker, eds. The land of promise - Biblical, theological and contemporary perspectives. Downers Grove: InterVarsity. p. 121141).

Robbins, D. 1990. A youth worker's guide to discipling teenagers. The ministry of nurture. Grand Rapids: Zondervan.

Spierling, K.E. 2005. Infant baptism in Reformation Geneva - The shaping of a community, 1536-1546. Aldershot: Ashgate.

Strommen M.P. 2000. Passing on the faith: a radical new model for youth and family ministry. Winona: Saint Mary's Press.

Tillich, P. 1948. The Protestant era (Translated and with a concluding essay by James Luther Adams).

Chicago: University of Chicago Press.

Van der Merwe, J. 2009. Ontdek die doop en geloofsbevestiging. (In C. Wepener and J. van der Merwe, eds., Ontdekkings in die erediens. Wellington: Lux Verbi.BM, p.129-145). [Discover baptism and confirmation of faith. (In C. Wepener and J. van der Merwe, eds., Discoveries in the worship service. Wellington: Lux Verbi.BM, p.129-145).]

Van 't Spijker, W. 1980. Zijn verbond en woorden - Over doop, belijdenis en avondmaal volgens de klassieke formulieren. Goudriaan: De Groot Uitgeverij.

Wainwright, G. 1978. The periods of liturgical history. (In C. Jones, G. Wainwright \& E. Yarnold, eds., The study of Liturgy. London: SPCK, p.33-38).

Willimon, W.H. 1980. Remember who you are: Baptism, a model for Christian life. Nashville: The Upper Room.

White, J.F. 1999. The sacraments in Protestant practice and faith. Nashville: Abingdon.

Wilson, D. 2003. Baptism and children: their place in the Old and New Testaments. (In G. Strawbridge, ed., The case for covenantal infant baptism. Phillipsburg: P\&R Publishing, p.286-310).

\section{KEY WORDS}

Liturgy

(Covenantal) space

Sacramental

Baptism

(Christian) Education

Prof. G Breed

Skool vir Kerkwetenskappe

Fakulteit Teologie

Noordwes Universiteit

Potchefstroom-kampus

\section{TREFWOORDE}

Liturgie

(Verbonds)ruimte

Sakramenteel

Doop

(Christelike) Opvoeding
Privaatsak X6001

Potchefstroom

2520

Tel: 018-2991029

e-pos: gert.breed@nwu.ac.za
Prof. FW De Wet

Skool vir Kerkwetenskappe

Fakulteit Teologie

Noordwes Universiteit

Potchefstroom-kampus

Privaatsak X6001

Potchefstroom

2520

Tel: 018-2991591

e-pos: fritz.dewet@nwu.

ac.za 